\title{
Study of cutting zone of WPC material after cold cutting
}

\author{
D. Mital ${ }^{1}$, ,M. Hatala ${ }^{1}$,J. Zajac ${ }^{1}$, P. Michalik ${ }^{1}$, J. Duplak ${ }^{1}$, J. Vybostek ${ }^{1}$, L. \\ Mroskova $^{1}$ and D. Knezo ${ }^{1}$
}

\begin{abstract}
Presented article is focused on monitoring the parameter of the surface integrity after cold cutting. Selected monitoring parameter was surface roughness $\mathrm{Ra}$ and $\mathrm{Rz}$ in the zone of cutting in three areas specially point of entering, middle part of the workpiece and end of the cutting surface. Experimental material was designed Wood Plastic Composite from the reason of unconventional material and new approach of studying mentioned material to obtain parametrical equation of the surface roughness. Presented article is based on needs from practice and present new scientific sight on material WPC.
\end{abstract}

Keywords: wood, plastic, composite, cutting zone, roughness.

\section{Introduction}

Composite materials are materials, which are composed of two and more materials with different characteristic specifications. Term Wood Plastic Composite (WPC) can be to define as composite materials, which is consisting of wood filler and polymer matrix. Wood filler mainly used in application is wood flour from various wood types to achieve reinforcement of thermoplastic matrix. Main advantage is low purchasing costs and low values of density. WPC are biodegradable with possibility to recycle what include them into green materials. Most common thermoplastic polymers used in WPC materials are polyethylene, polypropylene and polyvinylchloride. Combination of wood fillers and thermoplastic can be produced directly designed for selected application. Properties of composite materials can be set by various concentrations of the fillers, matrix and process variables such as temperature, pressure and stir. Manufacturing of the composite materials require 
high demand costs, which are connected on technologies and equipments (form, machine, maintenance and so on). Ration of wood in composite is usually from the range from $30 \%$ to $70 \%$. WPC is characterized by higher resistance, less water absorption and higher resistance to molds and fungus. Wood plastic composites do not require additional surface treatment and with wood ration over the $40 \%$ are characterized by higher temperature resistance $[3,7]$.

Nowadays are WPC mainly used in building industry as replacement of impregnated wood for terraces, railings, wood frames and so on. Currently WPC materials replace components in automotive industry, aerospace industry, electrician industry. Base assumption to achieve required properties is to appropriately choose raw materials[1].

Wood flour is obtained from wood particles from waste products in wood processing industry. Wood mass is from sawmill, furniture, joinery factories and mining in forest and comes in dissimilar sizes, moisture and blended with other substances. Woods flour (Tab. 1)consistency such as flour or sawdust, but can vary in size from fine powder up to the size of a grain of rice. All quality wood flour made from hard wood, because they are durable and strong (Fig. 9). Some flours are made of soft wood such as pine or fir. Wood flour is commonly used as filler in thermosetting resins, such as bakelite, and linoleum[5, 8].

Volume densities of the wood flour depend on several factors - moisture content, particles sizes and wood type. Wood flour is unusual for its compressibility, because during the process temperature and high pressure causes material compression. The value of specific weight is around $1300 \mathrm{~kg} \cdot \mathrm{m}-3[6]$.

Wood fibers are cellulose fibers which are obtained from wood, straw, bamboo, cotton seed, hemp, sugar cane and other natural materials. Due to the better mechanical properties compared to wood fiber wood flour it began to use wood fibers for the production of WPC. In general, the higher slenderness ratio, the better the mechanical properties. The physical and mechanical properties of the fibers are depending on the type of wood and the choice is largely influenced by the properties of the final product. The dimensions and the length of wood fibersis quite variable (Tab. 2) [7].

Lignin is a polymer of three-dimensional phenyl propanol which is aromatic and amorphous. Basic building block is phenyl propanol derivatives (ie. P-coumaryl alcohol, coniferyl alcohol, sinapyl alcohol) (Fig. 1). Lignin represents a special glue and the main reason of using lignin is to join the material in the cell wall, which supply appropriate stiffness and strength. The soft wood is $22-33 \%$ of wood, but with hardwood, this value is about $16-25 \%$. If we want to produce a quality material, the lignin needs to be removed from the wood $[1,5]$.

Thermoplastic matrixes used in WPC production have to be characterized by melting temperature under the $200^{\circ} \mathrm{C}$ from the reason of degradable of the wood particles at temperatures over the $200^{\circ} \mathrm{C}$. Currently used thermoplastic matrixes for manufacturing WPC are polyethylene with high density (HDPE), polypropylene (PP) and polyvinylchloride (PVC) [3].

Polyethylene (PE) it is the most produced plastic in the world. It has a relatively low melting point in the range between 106 and $130^{\circ} \mathrm{C}$ depending on the density. PE is produces by the polymerization of ethylene using several possibilities: radi- 
cal polymerization or anionic respectively cationic addition polymerization and the ionic coordination polymerization, any of these methods provides a polyethylene with different physical-mechanical properties [4].

Polypropylene or polypropene (abbreviation PP or POP) is a thermoplastic polymer from the polyolefin is used in many sectors including the food industry, textile industry and laboratory equipment. It is sold under the trade names Tipplen, Tatren. Its density is low and is about the value -0.920 .90 g.cm-3 [3, 6].

Polyvinyl chloride, abbreviated PVC is a plastic polymer made artificially. PVC is a plastic material that is widely used in construction, transportation, electrical electronic and medical devices, where. PVC is extremely durable and long-lasting construction material, which can be used in various applications, either rigid or flexible. Due to the properties of PVC is used in many sectors, and provides a great deal of popular and necessary products.

Following figure represent percentage ratio of using thermoplastic in the process of manufacturing wood plastic composites (Fig. 2) [2, 4].

Additives used in manufacturing process of WPC materials eliminate deficiency and problems connected with joining two different materials. Adhesion between hydrophobic plastic materials and hydrophilic of wood mass is quite on low level $[7,5]$.

Reason of use additives:

- Improve conditions during processing,

- Connecting of raw materials, higher level of resistance against biotic and abiotic factors,

Improve the mechanical and physical properties. Stabilizers:

- UV stabilizers - absorb UV radiation, which depredate polymers

- Thermo oxidation stabilizes - increase temperature level and time of use. Biocides:

- $\quad$ Significantly increase degradation of biotic factors, and eliminate grow of fungus and molds.

Polymers modifications:

- Substances that enhance impact resistance and extensibility of the composite.

Plasticizers:

- Volatile organic substances, which affect ductility, flexibility and a reduction in viscosity, increase the thermo-plasticity.

\section{Experimental part}

Experimental study is based on analyzing of cutting zone after cold cutting technologies (band saw and water jet). Cutting wood composite sample was realized with selected band saw Ergonomic 275.230 DG , which have sufficiently dimen- 
sioned drive motor, a gearbox with helical gears and oil fill and a large range of angular cuts from $-45^{\circ}$ to $+60^{\circ}$. The cutting is ensured by weight arm with hydraulic speed control. Precise hard metal rolling drives of the band saw, joint saw head mounted on tapered roller bearings, a $27 \mathrm{~mm}$ saw band and synchronizedrunning brush to remove chips are the prerequisites for excellent cutting performance. Adjustable clamping is designed to prevent the workpiece offices during the process of cutting.

Technical parameters and cutting parameters of the band saw were:

- Minimal cutting diameter $\varnothing 5 \mathrm{~mm}$, The shortest length of the rest: 20 $\mathrm{mm}$, Material laying height: $760 \mathrm{~mm}$, Blade dimensions (length $\mathrm{x}$ height $\mathrm{x}$ thickness): $2720 \mathrm{~mm}$ x $27 \mathrm{~mm}$ x $09 \mathrm{~mm}$, Drive power band: $1.1 / 1.5 \mathrm{~kW}$, Saw band speed: 40/80 m.min 1, Total installed power: $2.7 \mathrm{kVA}$, Dimensions (width $\mathrm{x}$ length $\mathrm{x}$ height): $640 \mathrm{~mm} \times 1400 \mathrm{~mm} \times 1270 \mathrm{~mm}$

- $\quad$ Cutting condition: Saw band speed: 80 m.min 1, Feed: 0,180m.min-1.

Cutting samples made of WPC realized by water jet were done on machine WJ 3020b-1 Z (Fig. 3).

Cutting conditions set for the experiment were:

- Cutting speed 100 mm.min-1, Type of abrasive: Australian grenade, Granularity abrasives: MESH 80, Diameter of the nozzle: $0.25 \mathrm{~mm}$, Guidance tube diameter: $1.12 \mathrm{~mm}$, Guidance tube length: $76 \mathrm{~mm}$.

Samples use for the experimental part was selected by various rate of wood manufactured by extruded technology. Individual depositions are shown in the table below (Fig. 4).

To measure the surface roughness of the pre-cut wood composite samples we were used Roughness Mitutoyo SJ 400th

The arithmetic mean deviation of the profile $\mathrm{Ra}$ is a height parameter and the average values of the heights and is defined as the arithmetic mean of the heights of the absolute values $\mathrm{Z}(\mathrm{x})$ within the regular length $\mathrm{lr}$.

Technical parameters during measuring process were set on following values: Measuring rate: $0.05 ; 0.1 ; 0.5 ; 1.0$ mm.s-1; Rate of return of $0.5 ; 1.0 ; 2.0 \mathrm{~mm} . \mathrm{s}-1$; Measuring direction: backward; Positioning: $\pm 1,5 \circ$ (slope), $10 \mathrm{~mm}$ (up / down); Range / measurement resolution: 800 / 0.01 microns; 80 / 0,001 microns; Supply type: via AC adapter; Evaluated parameters: P (primary), R (roughness), W (filtered waviness); Digital Filter: 2CR, PC75, Gauss; Cutoff length: 0.08; 0.25; 1.8; 2.5; $8 \mathrm{~mm}$. On each sample were measure realized 9 times with calculated mean values for top middle and end of the sample (Tab. 3) with calculated basic statistical indicators and also mathematical equations for each type of cutting as a dependence on wood percentage with correlation index over 95\% (1)(2) (Tab. 4).

$\mathrm{W}-\%$ of the wood

$\mathrm{P}-\%$ of the plastic

$$
\begin{aligned}
& \text { Rawj }=+0,4241 \cdot W^{2}-24,6272 . P+473,5791 \text { (1) } \\
& \mathrm{Ra}_{\mathrm{bs}}=0,4946 . \mathrm{W}^{2}-29,1777 . \mathrm{P}+570,5326 \text { (2) }
\end{aligned}
$$

Figure 5 (Fig. 5 a) shows comparison of the surface roughness after technological operation water jet and band saw cutting. The graphs have similar curves except that the surface roughness of the cutting band saw is greater than the water jet cutting. Subsequent figure (Fig. 5 b) represent comparison of surface roughness after 
cold cutting in the zone of the first contact of saw respectively water with workpiece. From the presented results can be stated, that surface affect on technology differently and boundary is $55 \%$, where individual curves changes their character (increase to rising and convex to concave). From this reason can be set result of the experiment of the use of technology to obtained the best quality surface: Use band saw for materials with wood ratio under the $55 \%$ and over mentioned board is supposed to use water jet technology.

\section{Conclusion}

The charts show the amount of wood\% dependence on the arithmetic mean deviation of the profile Ra considered and \% dependent on the amount of wood considered the largest height of roughness profile $\mathrm{Rz}$, which were measured using a roughness tester Mitutoyo SJ 400. The comparison of these graphs it can be seen that the \% of wood composite wood influences the surface quality.

Surface roughness depends on what kind of cutting materials with which it is used. For sample no. 4 to $50 \%$ of the wood is preferable because cutting band saw occurs less rougher surface than with water jet cutting. For samples with no. 5 to $55 \%$, and the sample timber no. 1 with $60 \%$ of the wood is better to cut water flow, but the surface arising from the cutting band saw is only slightly higher values. For samples with no.6 with $63 \%$ wood sample 2 with $65 \%$ of the wood and in a sample of $70 \%$ of the wood is better to cut the water jet.

\section{Acknowledgements.}

This research was financially supported by the project APVV $-15-0700$.

\section{References}

[1] NOURBAKHSH, N., ASHORI, A., Fundamental Studies on Wood-Plastic Composites: Effects of Fiber Concentration and Mixing Temperature on the Mechanical Properties of Poplar/PP Composite, Polymer Composites, Wiley InterScience, 2008, p. $569-573$

[2] KUO, P., WANG, S., CHEN, J., HSUEH, H., TSAI, M., Effects of materials compositions on the mechanical properties of wood-plastic composites manufactured by injection molding, Materials and Design, 2009, edt. 30, p. 3489-3496

[3] DUCHÁČEK, V., Polymery - Výroba ,vlastnosti, zpracování, použití, Vysokáškolachemicko-technologická v Praze, Praha, 2006, vyd. 2, str. 279, ISBN: 80-7080-6176 
[4] http://www.jelu-werk.com/technical-industry/applications/wood-plasticcomposite/,[Cit. 2016-09-09].

[5] HUTYROVA, Z. , ZAJAC, J. : Turning of composite material with organic reinforcement (wood plastic composite), Advanced Science Letters, Volume 19, Issue 3, March 2013, Pages 877-880

[6] VALÍČEK,J., HARNIČÁROVÁ,M., HLAVATÝ,I., GRZNÁRIK,R., KUŠNEROVÁ,M., HUTYROVÁ,Z., PANDA,A.: A new approach for the determination of technological parameters for hydroabrasive cutting of materials, Materialwissenschaft und Werkstofftechnik, volume 47, number 5-6,462-471.

[7] KRAVEC, M.. : Evaluation of cutting area after machining of Wood Plastic Composite, diploma thesis 2016

[8] DOBRÁNSKY, Jozef - BARON, Petr - KOČIŠKO, Marek - VOJNOVÁ, Eva: Monitoring of the influence of moisture content in thermoplastic granulate on rheological properties of material In: Applied Mechanics and Materials. Vol. 616 (2014), p. 207215. - ISSN 1660-9336 
Figure 1. Structures of the lignin derivates

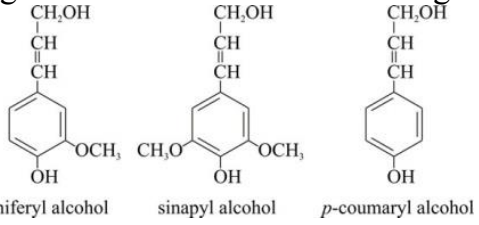

Figure 2. Thermoplastic used in WPC manufacturing

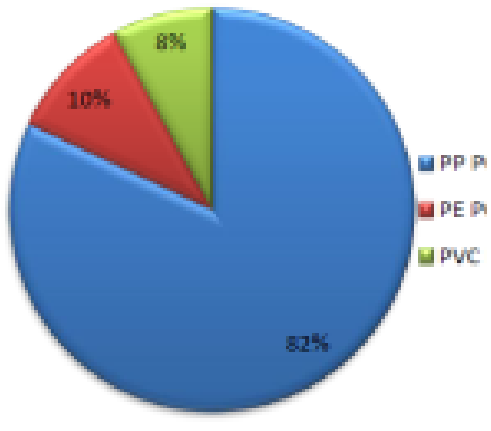

Figure 3. Water jet $3020 b-1 Z$

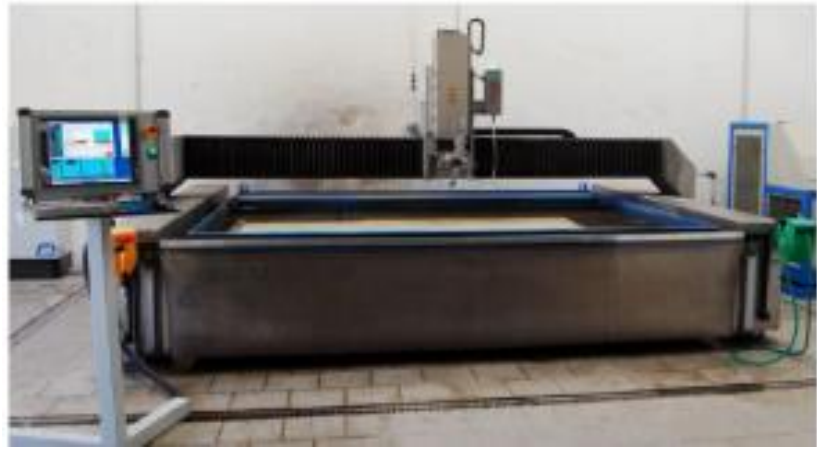


Figure 4. Experimental samples

\begin{tabular}{|c|c|c|c|c|c|}
\hline $\begin{array}{c}\text { Sample } \\
\text { number }\end{array}$ & Sample & Composition & $\begin{array}{c}\text { Sample } \\
\text { number }\end{array}$ & Sample & Composition \\
\hline 1 & & $\begin{array}{c}\text { Wood } 60 \% \\
\text { Plastic } 30 \% \\
\text { Additivies } 10 \%\end{array}$ & 4 & & $\begin{array}{c}\text { Wood } 50 \% \\
\text { Plastic } 45 \% \\
\text { Additivies } 5 \%\end{array}$ \\
\hline 2 & & $\begin{array}{c}\text { Wood } 65 \% \\
\text { Plastic } 35 \% \\
\text { Additivies } 5 \%\end{array}$ & 5 & & $\begin{array}{c}\text { Wood } 55 \% \\
\text { Plastic } 35 \% \\
\text { Additivies } 8 \%\end{array}$ \\
\hline 3 & & $\begin{array}{c}\text { Wood } 70 \% \\
\text { Plastic } 25 \% \\
\text { Additivies } 5 \%\end{array}$ & 6 & & $\begin{array}{c}\text { Wood } 63 \% \\
\text { Plastic } 30 \% \\
\text { Additivies } 7 \%\end{array}$ \\
\hline
\end{tabular}

Figure 5. Result of the experiment a) - roughness Ra measured at the end of the samples depend on wood ratio b) - roughness Ra at the beginning of the samples (Red line bend saw; Blue line- water jet)
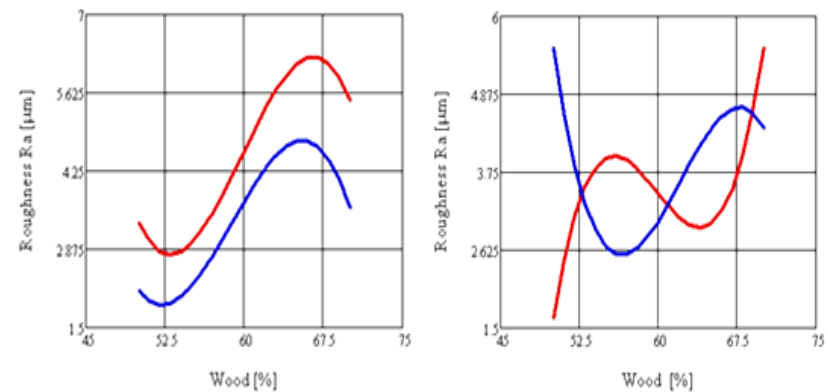
Table 1. Parameters of wood flour

\begin{tabular}{cccc}
\hline \multicolumn{4}{c}{ Parameters of wood flour } \\
\hline Density & Dimensions classes & Ratio & Humidity \\
{$[$ kg.m-3] } & {$[\boldsymbol{\mu m}]$} & length/toughness & {$[\%]$} \\
$\mathbf{1 9 0 - 2 2 0}$ & $50-150 ; 100-200 ;$ & $2: 1-5: 1$ & 4. VIII \\
& $200-450 ; 250-700$ & & \\
\hline
\end{tabular}

Table 2. Parameters wood fibers

\begin{tabular}{cccc}
\hline \multicolumn{4}{c}{ Parameters of wood fibers } \\
\hline $\begin{array}{c}\text { Fiber } \\
\text { type }\end{array}$ & Density [kg.m-3] & $\begin{array}{c}\text { Lenght } \\
{[\mathbf{m m}]}\end{array}$ & $\begin{array}{c}\text { Diameter } \\
{[\boldsymbol{\mu m}]}\end{array}$ \\
Linen & 1440 & $25-50$ & $15-18$ \\
Cotton & 1520 & $15-55$ & $10-17$ \\
Cannabis & 1480 & $15-20$ & $15-50$ \\
$\begin{array}{c}\text { Soft } \\
\text { wood } \\
\text { Hard } \\
\text { wood }\end{array}$ & $1440-1550$ & $0,7-11$ & $2-12$ \\
\hline
\end{tabular}

Table 3. Measured values of the surface roughness for the sample 1

\begin{tabular}{|c|c|c|c|c|c|c|c|c|c|c|c|c|}
\hline \multirow[t]{2}{*}{ METHOD } & \multirow[t]{2}{*}{ ROUGHNESS } & \multirow{2}{*}{$\begin{array}{c}\text { Place of } \\
\text { Measuring }\end{array}$} & \multicolumn{9}{|c|}{ Number of measuring } & \multirow[t]{2}{*}{ Mean } \\
\hline & & & 1 & 2 & 3 & 4 & 5 & 6 & 7 & 8 & 9 & \\
\hline \multirow[t]{4}{*}{ Water Jet } & $\mathrm{Ra} \mu \mathrm{m}$ & beginning & 2,4 & 2,4 & 2,4 & 2,4 & 2,4 & 2,4 & 2,4 & 2,4 & 2,4 & 2,38 \\
\hline & $\mathrm{Rz} \mu \mathrm{m}$ & beginning & 14 & 14 & 14 & 14 & 14 & 14 & 14 & 14 & 14 & 14,06 \\
\hline & $\mathrm{Ra} \mu \mathrm{m}$ & end & 3,1 & 3,2 & 3,2 & 3,1 & 3,2 & 3,2 & 3,2 & 3,2 & 3 & 3,125 \\
\hline & $\mathrm{Rz} \mu \mathrm{m}$ & end & 18 & 18 & 17 & 18 & 18 & 17 & 18 & 18 & 18 & 17,65 \\
\hline \multirow[t]{4}{*}{ Band saw } & $\mathrm{Ra} \mu \mathrm{m}$ & beginning & 2,8 & 3,3 & 3,3 & 2,9 & 3 & 3,2 & 2,9 & 3,3 & 3,1 & 3,06 \\
\hline & $\mathrm{Rz} \mu \mathrm{m}$ & beginning & 18 & 17 & 17 & 18 & 18 & 17 & 18 & 17 & 17 & 17,25 \\
\hline & $\mathrm{Ra} \mu \mathrm{m}$ & end & 2,9 & 2,8 & 2,8 & 2,8 & 2,8 & 2,9 & 2,8 & 2,8 & 2,8 & 2,81 \\
\hline & $\mathrm{Rz} \mu \mathrm{m}$ & end & 17 & 16 & 17 & 16 & 17 & 17 & 17 & 17 & 17 & 16,65 \\
\hline
\end{tabular}


Table 4. Statistical indicators

\begin{tabular}{ccc}
\hline Measuring place & Dispersion & Standard deviation \\
\hline Beginning WJ & 2,23 & 1,57 \\
End WJ & 123 & 1,11 \\
Beginning BS & 1,44 & 1,2 \\
End BS & 2,27 & 1,5 \\
\hline
\end{tabular}

